\title{
Granulomatosis with polyangiitis mimics ST-elevation myocardial infarction
}

${ }^{1}$ Department of Internal Medicine I, University Hospital Jena, Jena, Thueringen, Germany ${ }^{2}$ Institute of Diagnostic and Interventional Radiology, University Hospital Jena, Jena, Thueringen, Germany ${ }^{3}$ Department of Internal Medicine III, University Hospital Jena, Jena, Thueringen, Germany

Correspondence to Dr Marcus Franz;

marcus.Franz@med.uni-jena.de

Accepted 13 April 2020

Check for updates

(C) BMJ Publishing Group Limited 2020. No commercial re-use. See rights and permissions. Published by BMJ.

To cite: Franz M, Renz D,
Wolf G, et al. BMJ Case
Rep 2020;13:e234728.
doi:10.1136/bcr-2020-
234728

\author{
Marcus Franz, ${ }^{1}$ Diane Renz, ${ }_{1}^{2}$ Gunter Wolf, ${ }^{3}$ Alexander Pfeil ${ }^{3}$
}

\section{DESCRIPTION}

A 57-year-old male patient with a history of dyspnoea was admitted to the hospital for exertion, fatigue and joint pain experienced in the last month. The patient had been treated in another hospital for pneumonia with antibiotic therapy. The pneumonia did not improve, and the patient reported weight loss in the last months and experienced episodes of haemoptysis. Clinical examination revealed no abnormalities. The ECG showed elevated ST segments in the leads II, III and aVF as well as an inversion of the $\mathrm{T}$ waves in $\mathrm{aVL}$, V1 and V2 (figure 1A). Troponin I was increased with $24918.40 \mathrm{pg} / \mathrm{mL}$ (reference: $<34.2 \mathrm{pg} / \mathrm{mL}$ ). Further laboratory findings showed elevation of the C-reactive protein by $30 \mathrm{mg} / \mathrm{L}$ (reference: $<2.0 \mathrm{mg} / \mathrm{L}$ ) and an erythrocyte sedimentation rate of $81 \mathrm{~mm} /$ first hour (reference: $<20 \mathrm{~mm} /$ first hour). Transthoracic echocardiography showed a reduced left ventricular ejection fraction of $40 \%$ and a left ventricular thrombus (figure 1B). Atherosclerotic obstructive coronary artery disease was excluded by coronary angiography.
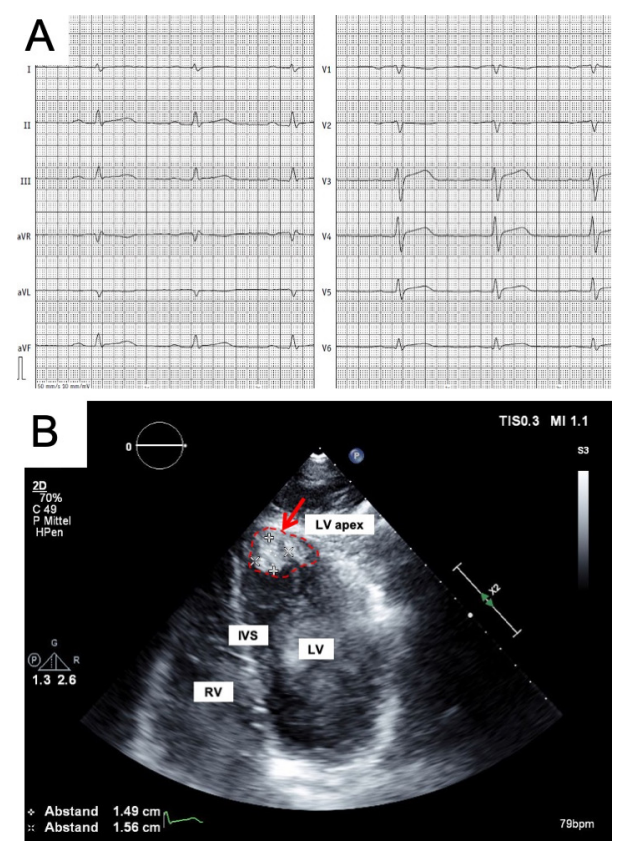

Figure 1 (A) ECG with elevated ST segments (II, III and $\mathrm{aVF}$ ) and inversion of the $\mathrm{T}$ waves $\left(\mathrm{aVL}, \mathrm{V}_{1}\right.$ and $\left.\mathrm{V}_{2}\right)$. (B) Transthoracic echocardiography with a reduced left ventricular ejection fraction (40\%) and a left ventricular thrombus (red arrow and dotted line) (IVS, interventricular septum; LV, left ventricle; RV, right ventricle).

\section{Learning points}
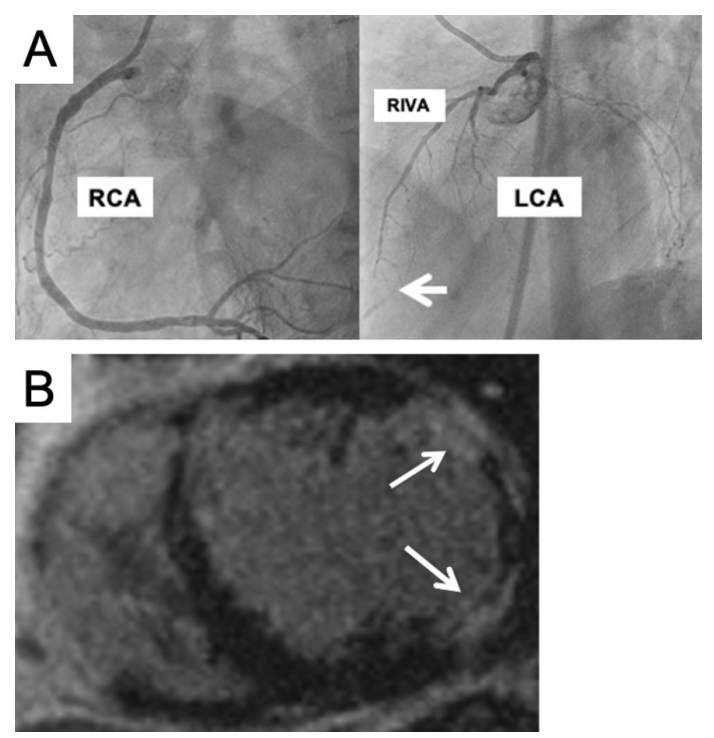

Figure 2 (A) Coronary angiography with absence of coronary heart disease (arrow: distal Ramus interventricularis anterior (RIVA) with thrombus formation; LCA: left coronary artery; RCA, right coronary artery). (B) MRI with delayed myocardial enhancement of the left ventricular myocardium (arrows).

The examination presented most probably inflammatory obstruction of the distal Ramus interventricularis anterior with thrombus formation (figure 2A). MRI showed a delayed myocardial enhancement of the left ventricle myocardium (figure 2B). Further laboratory testing showed high positive autoantibodies against proteinase 3 (158.3 U/mL, reference: $1-10 \mathrm{U} / \mathrm{mL}$ ) and cANCA (titre: 1:100, reference: negative). The final diagnosis based on the clinical and laboratory findings as well as imaging was granulomatosis with polyangiitis, with cardiac involvement.

Granulomatosis with polyangiitis is a rare systemic inflammatory disorder characterised by vasculitis of the small arteries, the arterioles and the capillaries together with necrotising granulomatous lesions.

- In rare cases, the disease shows cardiac involvement. ${ }^{1}$

- Cardiac involvement is associated with increased troponin I and delayed myocardial enhancement as a sign of inflammation in small vessel vasculitis. 
Contributors MF and AP treated the patient, reported the clinical course, designed the manuscript and interpreted the findings. DR performed important imaging studies of the patient, designed the manuscript and interpreted the findings. GW treated the patient and contributed to data interpretation.

Funding The authors have not declared a specific grant for this research from any funding agency in the public, commercial or not-for-profit sectors.

Competing interests None declared.
Patient consent for publication Obtained.

Provenance and peer review Not commissioned; externally peer reviewed.

\section{REFERENCE}

1 Raghunathan V, Pelcovits A, Gutman D, et al. Cardiogenic shock from coronary vasculitis in granulomatosis with polyangiitis. BMJ Case Rep 2017;2017:2017.

Copyright 2020 BMJ Publishing Group. All rights reserved. For permission to reuse any of this content visit https://www.bmj.com/company/products-services/rights-and-licensing/permissions/

BMJ Case Report Fellows may re-use this article for personal use and teaching without any further permission.

Become a Fellow of BMJ Case Reports today and you can:

- Submit as many cases as you like

- Enjoy fast sympathetic peer review and rapid publication of accepted articles

- Access all the published articles

Re-use any of the published material for personal use and teaching without further permission

Customer Service

If you have any further queries about your subscription, please contact our customer services team on +44 (0) 2071111105 or via email at support@bmj.com.

Visit casereports.bmj.com for more articles like this and to become a Fellow 